\title{
Effect of days in feedlot on growth performance and carcass characteristics of Merino, South African Mutton Merino and Dorper lambs
}

\author{
T.S. Brand ${ }^{1,2 \#}$, E.J. van der Westhuizen ${ }^{2}$, D.A. van der Merwe ${ }^{2}$ \& L.C. Hoffman ${ }^{2}$ \\ 1Directorate: Animal Sciences, Department of Agriculture, Western Cape Government, Private Bag X1, Elsenburg, 7607, \\ South Africa. \\ ${ }^{2}$ Department of Animal Sciences, University of Stellenbosch, Private Bag X1, Matieland, 7602, South Africa
}

(Received 25 April 2016; Accepted 21 November 2016; First published online 8 December 2016)

Copyright resides with the authors in terms of the Creative Commons Attribution 4.0 South African License.
See: http://creativecommons.org/licenses/by/4.0/za
Condition of use: The user may copy, distribute, transmit and adapt the work, but must recognize the authors and the South African
Journal of Animal Science.

\begin{abstract}
This study investigated the effect of feedlot production on lamb growth characteristics of three common South African breeds: Merino, South African Mutton Merino (SAMM) and Dorper. Lambs were supplied with a balanced diet (16\% crude protein, $9.41 \mathrm{MJ} \mathrm{ME} / \mathrm{kg}$ feed) ad libitum and had free access to water. Lambs from each breed were divided into six groups. One group of each breed was slaughtered every three weeks until 105 days under feedlot production were reached. The weights of the lambs were recorded weekly, along with feed intake, to obtain the individual daily intake, average daily gain (ADG) and feed conversion ratio (FCR) for each lamb. The ADG for the SAMM 2007 and Dorper lambs increased throughout their production period, while that of the SAMM 2008 and Merino lambs tended to decrease with time, although the SAMM 2008 group achieved the highest ADG of $350.2 \mathrm{~g} / \mathrm{lamb} /$ day of all the breeds. The Dorper and SAMM 2007 lambs had higher FCR (7.52 and 7.58, respectively). The average FCR achieved by the SAMM 2008 and Merino lambs was 5.54 and 5.14, respectively. However, the FCR of Merino and SAMM 2008 lambs increased throughout the production period. The Dorper lambs produced fatter carcasses and therefore exhibited the highest average dressing percentage of $49.7 \%$ compared with the SAMM 2007 (48.4\%) and 2008 lambs (45.6\%), followed by the Merino lambs (43.9\%). The results confirm that the Merino is a late maturing breed that is recognised for its wool rather than meat production, and therefore exhibits weaker growth characteristics. The SAMM is a dual-purpose breed that has also been selected for growth and meat production, and therefore exhibits desirable production characteristics, while the Dorper is an early maturing breed that deposits localized fat at an earlier age as it grows, thereby producing fatter carcasses than SAMM and Merino lambs. Therefore, Dorper lambs should be slaughtered at lower live weights so that carcasses are not graded as over-fat.
\end{abstract}

Keywords: average daily gain, breeds, feed conversion ratio, sheep

\#Corresponding author: tersb@elsenburg.com

\section{Introduction}

Animal growth is defined as an increase in bodyweight that is achieved by hypertrophy and hyperplasia until a mature size is reached, accompanied by changes in body conformation (Lawrie, 1998). Mature size is generally regarded as the point of maximum muscle mass at which the level of fat deposition increases (Owens et al., 1993). Although genotype is the main dictator of lamb growth potential, growth rate and development can be manipulated by environmental and nutritional factors (Aberle et al., 2001). Feedlot diets are designed to maximize growth rate and minimize the number of days on feed (Notter et al., 1991). The higher energy content in concentrate rations is responsible for this effect (Sanchez \& Alfonso, 1998), leading to a superior ADG compared with lambs produced on pasture (Priolo et al., 2002). In small ruminants, the level of feed intake is determined and regulated by dietary energy density (Lu \& Potchoiba, 1990).

In this study, early, medium and late maturing sheep breeds that are common in South Africa were finished under feedlot conditions. The late-maturing Merino is a wool-type breed that can produce a carcass with good conformation and fat cover, because of adaptations in their breeding strategy for an improved meat production capability (Olivier, 1999). The SAMM is a medium-maturing mutton-wool sheep (80 mutton : 20 wool), which is able to produce slaughter lambs with high growth rates at an early age with excellent meat quality attributes (Cloete et al., 2004). The SAMM has an excellent FCR (Sheridan et al., 2003) and is 
therefore a popular breed in feedlot production systems (Neser et al., 2000). The Dorper is an early maturing mutton breed that produces fast growing lambs with good carcass quality characteristics (Schoeman, 2000). Therefore it tends to put on more localized fat at an earlier age than late maturing breeds. In South Africa, all three breeds are commonly finished off under feedlot conditions. However, the industry tends to slaughter sheep after a fixed number of days in the feedlot rather than when they reach a predetermined level of subcutaneous fat. More research is required to indicate to the industry whether breed needs to be considered when deciding at what stage to slaughter feedlot finished lambs.

\section{Materials and Methods}

Lambs for the studies were obtained from the experimental flocks of Western Cape Department of Agriculture, which vary in size. Hence, the groups housed in the trial had unequal numbers. Merino, SAMM and Dorper lambs were finished off under feedlot conditions and slaughtered at different ages. In 2007 groups of 113 Merino lambs, 126 SAMM lambs and 29 Dorper lambs were housed at Elsenburg Experimental Farm under feedlot conditions. Data were collected in 2008 from a group of 105 SAMM lambs. It was decided to repeat the trial for SAMM lambs in 2008 to confirm the results obtained in 2007. Because feed resources were insufficient in 2008, the lambs were weaned at about 141 days old, compared with 2007, when they were weaned at about 122 days, to ensure that lambs attained a desirable weaning weight. All lambs were vaccinated against pulpy kidney (Clostridia perfringes $D$ ) and drenched against internal parasites before entering the feedlot.

Lambs were allocated randomly to pens in the feedlot, and were not subjected to an adaptation period. The lambs were fed a commercially available balanced diet ( $16 \%$ crude protein, $9.41 \mathrm{MJ} \mathrm{ME} / \mathrm{kg}$ feed) individually on an ad libitum basis and had free access to water. The physical and chemical compositions of the trial diet are shown in Table 1. Individual lamb weights were recorded at the beginning of each week to determine ADG. Fresh feed was weighed and provided daily to the lambs. At the end of each week, refusals were weighed back to determine individual feed intake.

Table 1 Composition of the feedlot diet

\begin{tabular}{lclc}
\hline Ingredients & As fed $(\mathrm{g} / \mathrm{kg})$ & Nutrients & As Fed \\
\hline Lucerne hay & 485.1 & Energy $(\mathrm{MJ} \mathrm{ME} / \mathrm{kg}$ feed) & 9.41 \\
Maize & 394.9 & Crude protein $(\mathrm{g} / \mathrm{kg})$ & 160 \\
Cottonseed oilcake meal & 57.9 & Non degradable protein $(\mathrm{g} / \mathrm{kg})$ & 34.6 \\
Calorie 3000 (molasses powder) & 25.0 & Rumen degradable protein $(\mathrm{g} / \mathrm{kg})$ & 125.4 \\
Salt & 10.0 & Total digestible nutrients $(\mathrm{g} / \mathrm{kg})$ & 630.0 \\
Urea & 5.0 & Crude fibre $(\mathrm{g} / \mathrm{kg})$ & 160.9 \\
Ammonium sulphate & 5.0 & Acid detergent fibre $(\mathrm{g} / \mathrm{kg})$ & 209.8 \\
Slaked lime & 5.0 & Neutral detergent fibre $(\mathrm{g} / \mathrm{kg})$ & 286.8 \\
Ammonium chloride & 5.0 & Calcium $(\mathrm{g} / \mathrm{kg})$ & 14.7 \\
Limestone & 5.0 & Phosphorous $(\mathrm{g} / \mathrm{kg})$ & 30.0 \\
Mono calcium phosphate & 2.1 & & \\
\hline Total & 1000.00 & & \\
\hline
\end{tabular}

ME- Metabolisable energy

The lambs were randomly divided into six slaughter groups at the initiation of the feedlot trial. The control group was not housed in the feedlot as these lambs were slaughtered at weaning. Thereafter, a group of lambs were slaughtered at a commercial abattoir every 21 days. The last groups of Dorper and SAMM lambs were slaughtered after 105 days under feedlot conditions and after 98 days for the Merino lambs. Each slaughter group was weighed 24 hours prior to slaughter. This weight was used as the animal's final slaughter weight. Lambs were kept in lairage at the abattoirs for 18 hours before slaughter to allow sufficient resting time and water was provided ad libitum. Lambs were stunned electrically, slaughtered with standard South African techniques and classified according to age and backfat thickness (Cloete et al., 2008). Carcass weight was recorded 48 hours post mortem, excluding the kidneys and renal fat. The subcutaneous fat depth was measured on the longissimus lumborum, after the carcasses had been 
butchered at a deboning facility. The fat depth was measured with an electronic calliper at the 13th rib (Gilmour et al., 1994) $25 \mathrm{~mm}$ from the midline of the spine.

\section{Results}

Feedlot production and slaughter data were collected for the three breeds and are presented in Tables 2 to 5 . Live weight, carcass weight and subcutaneous fat depth increased with time spent in the feedlot for all breeds.

Table 2 Least square means $( \pm$ S.E.) depicting the effect of feedlot production on Merino lambs that were weaned at about 109 days old

\begin{tabular}{|c|c|c|c|c|c|c|c|c|}
\hline $\begin{array}{l}\text { Days in } \\
\text { feedlot }\end{array}$ & $\mathrm{n}$ & $\begin{array}{c}\text { Feed intake } \\
\text { (kg/ lamb/ } \\
\text { day) }\end{array}$ & $\begin{array}{l}\text { ADG (kg/ } \\
\text { lamb/ day) }\end{array}$ & $\begin{array}{c}\text { FCR (kg } \\
\text { intake/kg } \\
\text { weight gain) }\end{array}$ & $\begin{array}{l}\text { Slaughter } \\
\text { weight (kg) }\end{array}$ & $\begin{array}{c}\text { Carcass } \\
\text { weight }(\mathrm{kg})\end{array}$ & $\begin{array}{c}\text { Dressing } \\
\text { percentage } \\
(\%)\end{array}$ & $\begin{array}{l}\text { Fat depth } \\
\quad(\mathrm{mm})\end{array}$ \\
\hline 0 & 20 & - & - & - & $33.0 \pm 1.23$ & $11.9 \pm 0.75$ & $29.0 \pm 2.05$ & $0.6 \pm 0.47$ \\
\hline 21 & 18 & $1.370 \pm 0.02$ & $0.337 \pm 0.03$ & $2.8 \pm 1.23$ & $36.2 \pm 1.32$ & $15.2 \pm 0.72$ & $41.8 \pm 0.56$ & $2.2 \pm 0.43$ \\
\hline 42 & 19 & $1.533 \pm 0.04$ & $0.298 \pm 0.01$ & $5.3 \pm 0.25$ & $42.7 \pm 1.36$ & $18.5 \pm 0.73$ & $43.3 \pm 0.44$ & $3.4 \pm 0.41$ \\
\hline 63 & 18 & $1.660 \pm 0.04$ & $0.291 \pm 0.01$ & $5.9 \pm 0.33$ & $48.8 \pm 1.48$ & $21.2 \pm 0.84$ & $43.4 \pm 0.87$ & $6.3 \pm 0.43$ \\
\hline 77 & 19 & $1.624 \pm 0.01$ & $0.234 \pm 0.01$ & $7.2 \pm 0.37$ & $49.0 \pm 1.52$ & $22.7 \pm 1.08$ & $46.3 \pm 1.53$ & $4.8 \pm 0.41$ \\
\hline 98 & 19 & $1.598 \pm 0.00$ & $0.206 \pm 0.01$ & $7.9 \pm 0.26$ & $51.2 \pm 1.39$ & $23.0 \pm 0.83$ & $44.9 \pm 0.68$ & $7.6 \pm 0.41$ \\
\hline
\end{tabular}

ADG- Average daily gain

FCR- Feed conversion ratio

The highest ADG observed for Merino lambs was $0.337 \mathrm{~kg} /$ day after 21 days in the feedlot (Table 2). As time spent under feedlot conditions increased, ADG was seen to decrease, while the FCR tended to increase as the animals became older. The dressing percentage of the carcasses also tended to increase with time spent in the feedlot.

Table 3 Least square means ( \pm S.E.) depicting the effect of feedlot production on SAMM 2007 lambs that were weaned at about 122 days old

\begin{tabular}{lcccccccc}
\hline $\begin{array}{l}\text { Days in } \\
\text { feedlot }\end{array}$ & $\mathrm{n}$ & $\begin{array}{c}\text { Feed intake } \\
\text { (kg/ lamb/ } \\
\text { day) }\end{array}$ & $\begin{array}{c}\text { ADG }(\mathrm{kg} / \\
\text { lamb/ day) }\end{array}$ & $\begin{array}{c}\text { FCR }(\mathrm{kg} \\
\text { intake/kg } \\
\text { weight gain) }\end{array}$ & $\begin{array}{c}\text { Slaughter } \\
\text { weight }(\mathrm{kg})\end{array}$ & $\begin{array}{c}\text { Carcass } \\
\text { weight }(\mathrm{kg})\end{array}$ & $\begin{array}{c}\text { Dressing } \\
\text { percentage } \\
(\%)\end{array}$ & $\begin{array}{c}\text { Fat depth } \\
(\mathrm{mm})\end{array}$ \\
\hline & & & - & - & $35.3 \pm 1.20$ & $16.1 \pm 0.63$ & $45.5 \pm 2.00$ & $2.2 \pm 0.45$ \\
0 & 21 & - & - & - & & & & \\
21 & 21 & $1.448 \pm 0.05$ & $0.236 \pm 0.02$ & $10.3 \pm 2.80$ & $41.0 \pm 1.22$ & $19.4 \pm 0.67$ & $47.1 \pm 0.52$ & $3.2 \pm 0.45$ \\
42 & 21 & $1.893 \pm 0.03$ & $0.294 \pm 0.01$ & $6.5 \pm 0.22$ & $48.6 \pm 1.29$ & $23.3 \pm 0.69$ & $47.9 \pm 0.42$ & $5.4 \pm 0.45$ \\
63 & 22 & $1.860 \pm 0.03$ & $0.274 \pm 0.01$ & $7.2 \pm 0.43$ & $51.0 \pm 1.34$ & $25.3 \pm 0.76$ & $49.4 \pm 0.79$ & $5.9 \pm 0.44$ \\
84 & 21 & $1.947 \pm 0.03$ & $0.287 \pm 0.01$ & $6.8 \pm 0.22$ & $59.4 \pm 1.44$ & $30.2 \pm 1.12$ & $50.7 \pm 1.13$ & $7.5 \pm 0.45$ \\
105 & 20 & $1.944 \pm 0.02$ & $0.294 \pm 0.01$ & $6.7 \pm 0.17$ & $67.3 \pm 1.35$ & $33.4 \pm 0.81$ & $49.6 \pm 0.66$ & $12.0 \pm 0.46$
\end{tabular}

ADG- Average daily gain.

FCR- Feed conversion ratio.

SAMM- South African Mutton Merino.

For the SAMM 2007 production group, general increases in daily feed intake and ADG were observed. Dressing out percentage also tended to increase up to 84 days in the feedlot. The high FCR value of 10.3 observed for the group slaughtered after 21 days in the feedlot may be as a result of complications with animals adapting to the feedlot diet. 
Table 4 Least square means ( \pm S.E.) depicting the effect of feedlot production on SAMM 2008 lambs that were weaned at about 141 days old

\begin{tabular}{|c|c|c|c|c|c|c|c|c|}
\hline $\begin{array}{l}\text { Days in } \\
\text { feedlot }\end{array}$ & $\mathrm{n}$ & $\begin{array}{c}\text { Feed intake } \\
\text { (kg/ lamb/ } \\
\text { day) }\end{array}$ & $\begin{array}{l}\text { ADG (kg/ } \\
\text { lamb/ day) }\end{array}$ & $\begin{array}{c}\text { FCR (kg } \\
\text { intake/kg } \\
\text { weight gain) }\end{array}$ & $\begin{array}{c}\text { Slaughter } \\
\text { weight (kg) }\end{array}$ & $\begin{array}{c}\text { Carcass } \\
\text { weight }(\mathrm{kg})\end{array}$ & $\begin{array}{c}\text { Dressing } \\
\text { percentage } \\
(\%)\end{array}$ & $\begin{array}{l}\text { Fat depth } \\
\quad(\mathrm{mm})\end{array}$ \\
\hline 0 & 23 & - & - & - & $31.1 \pm 1.14$ & $13.9 \pm 0.61$ & $44.2 \pm 1.91$ & $1.8 \pm 0.55$ \\
\hline 21 & 24 & $1.385 \pm 0.02$ & $0.440 \pm 0.02$ & $3.3 \pm 0.16$ & $39.0 \pm 1.35$ & $17.8 \pm 0.74$ & $45.5 \pm 0.58$ & $1.3 \pm 0.65$ \\
\hline 42 & 24 & $1.729 \pm 0.03$ & $0.375 \pm 0.02$ & $4.8 \pm 0.20$ & $46.9 \pm 1.44$ & $22.4 \pm 0.77$ & $47.6 \pm 0.47$ & $4.1 \pm 0.67$ \\
\hline 63 & 25 & $1.817 \pm 0.04$ & $0.336 \pm 0.01$ & $5.5 \pm 0.13$ & $53.5 \pm 1.52$ & $26.2 \pm 0.87$ & $48.9 \pm 0.90$ & $4.9 \pm 0.65$ \\
\hline 84 & 25 & $1.987 \pm 0.03$ & $0.340 \pm 0.01$ & $5.9 \pm 0.09$ & $59.2 \pm 1.65$ & $25.7 \pm 0.92$ & $43.2 \pm 1.09$ & $9.3 \pm 0.67$ \\
\hline 105 & 24 & $2.097 \pm 0.05$ & $0.332 \pm 0.01$ & $6.4 \pm 0.18$ & $64.9 \pm 1.56$ & $28.5 \pm 0.93$ & $43.9 \pm 0.76$ & $13.0 \pm 0.69$ \\
\hline
\end{tabular}

ADG- Average daily gain.

FCR- Feed conversion ratio.

SAMM- South African Mutton Merino.

The starting weight of the SAMM 2008 lambs was lower than that of the SAMM 2007 lambs because feed resources were more abundant in 2007, which resulted in the 2007 lambs attaining heavier weaning weights at a younger age. For the SAMM 2008 production group feed intake, FCR and subcutaneous fat depth tended to increase with time spent in the feedlot, while ADG generally decreased (Table 4). The dressing percentage of the SAMM 2008 carcasses tended to increase up until 63 days in the feedlot, similarly to that of the SAMM 2007 production group at 84 days (Table 3). However, the dressing percentages for the last two slaughter groups were much lower than those observed in 2007 production group.

Table 5 Least square means ( \pm S.E.) depicting the effect of feedlot production on Dorper lambs that were weaned at 109 days old

\begin{tabular}{lcccccccc}
\hline $\begin{array}{c}\text { Days in } \\
\text { feedlot }\end{array}$ & $\mathrm{n}$ & $\begin{array}{c}\text { Feed intake } \\
\text { (kg/ lamb/ } \\
\text { day) }\end{array}$ & $\begin{array}{c}\text { ADG }(\mathrm{kg} / \\
\text { lamb/ day })\end{array}$ & $\begin{array}{c}\text { FCR }(\mathrm{kg} \\
\text { intak/kg } \\
\text { weight gain })\end{array}$ & $\begin{array}{c}\text { Slaughter } \\
\text { weight }(\mathrm{kg})\end{array}$ & $\begin{array}{c}\text { Carcass } \\
\text { weight }(\mathrm{kg})\end{array}$ & $\begin{array}{c}\text { Dressing } \\
\text { percentage } \\
(\%)\end{array}$ & $\begin{array}{c}\text { Fat depth } \\
(\mathrm{mm})\end{array}$ \\
\hline 0 & 5 & - & - & - & $36.6 \pm 3.07$ & $17.4 \pm 1.30$ & $47.2 \pm 4.10$ & $0.1 \pm 1.94$ \\
21 & 5 & $1.320 \pm 0.05$ & $0.134 \pm 0.05$ & $7.1 \pm 1.77$ & $36.1 \pm 2.30$ & $18.2 \pm 1.37$ & $50.2 \pm 1.06$ & $5.8 \pm 1.76$ \\
42 & 5 & $1.870 \pm 0.11$ & $0.260 \pm 0.04$ & $7.9 \pm 1.24$ & $43.3 \pm 3.65$ & $21.5 \pm 1.41$ & $49.6 \pm 0.87$ & $5.6 \pm 1.76$ \\
63 & 4 & $2.093 \pm 0.18$ & $0.268 \pm 0.01$ & $7.8 \pm 0.72$ & $51.3 \pm 1.49$ & $26.5 \pm 1.78$ & $51.6 \pm 1.85$ & $10.9 \pm 1.96$ \\
84 & 5 & $2.082 \pm 0.03$ & $0.279 \pm 0.03$ & $7.9 \pm 0.98$ & $62.4 \pm 4.57$ & $28.3 \pm 1.59$ & $48.3 \pm 1.45$ & $15.7 \pm 1.76$ \\
105 & 5 & $1.987 \pm 0.01$ & $0.285 \pm 0.01$ & $7.0 \pm 0.34$ & $61.8 \pm 2.15$ & $31.9 \pm 1.62$ & $51.5 \pm 1.32$ & $20.4 \pm 1.76$
\end{tabular}

ADG- Average daily gain

FCR- Feed conversion ratio

For the Dorper group, ADG and subcutaneous fat depth tended to increase with time in the feedlot. The Dorper lambs exhibited a high degree of fat deposition, indicated by the depth of subcutaneous fat on the longissimus lumborum muscle.

Regression equations were developed to describe the changes in slaughter weight, ADG and feed intakes of the lambs with time spent in the feedlot, and are shown in Tables 6 to 8 . The weights of the lambs at slaughter were seen to increase linearly, with high $R^{2}$ coefficients of determination for all production groups (Table 6). Quadratic regressions were found to be better suited to describing the change of ADG with days spent in the feedlot (Table 7). When differentiating the sigmoidal growth curve of an animal to obtain the slope or change in ADG, the differential typically results in a bell-shaped curve characteristic of a quadratic function. ADG increases from birth until a maximum point is reached, representing when the animal reaches the point of inflection on its growth curve, after which the growth rate decreases as the animal nears its mature live weight (Emmans, 1989). The negative values of the $b$ parameters for the 
regressions of the Merino and SAMM 2008 lambs indicate that the ADG of lambs in these production groups tended to show a decrease with days in the feedlot.

Table 6 Parameter means ( \pm S.E.) and $R^{2}$ coefficients of determination for the linear regressions to describe the change in slaughter weight for lambs from the Merino, SAMM 2007, SAMM 2008 and Dorper production groups

\begin{tabular}{lccc}
\hline Production group & $a$ & $b$ & $\mathrm{R}^{2}$ \\
\hline Merino & $32.0 \pm 1.68$ & $0.219 \pm 0.03$ & 0.94 \\
SAMM 2007 & $35.0 \pm 1.16$ & $0.295 \pm 0.02$ & 0.99 \\
SAMM 2008 & $31.7 \pm 1.18$ & $0.307 \pm 0.02$ & 0.99 \\
Dorper & $32.1 \pm 2.29$ & $0.306 \pm 0.04$ & 0.95
\end{tabular}

Equation of the form $\mathrm{y}=a+b \mathrm{x}$, where $\mathrm{x}$ represents days in the feedlot.

SAMM- South African Mutton Merino.

Table 7 Parameter means ( \pm S.E.) and $R^{2}$ coefficients of determination for the quadratic regressions to describe the change in ADG for lambs from the Merino, SAMM 2007, SAMM 2008 and Dorper production groups

\begin{tabular}{lcccc}
\hline Production group & $a$ & $b$ & $c$ & $\mathrm{R}^{2}$ \\
\hline Merino & $0.363 \pm 0.05$ & $-0.001 \pm 0.00$ & $-0.00001 \pm 0.00$ & 0.92 \\
SAMM 2007 & $0.208 \pm 0.05$ & $0.002 \pm 0.00$ & $-0.00001 \pm 0.00$ & 0.60 \\
SAMM 2008 & $0.520 \pm 0.02$ & $-0.004 \pm 0.00$ & $0.00003 \pm 0.00$ & 0.97 \\
Dorper & $0.031 \pm 0.06$ & $0.006 \pm 0.00$ & $-0.00004 \pm 0.00$ & 0.91
\end{tabular}

Quadratic equation of the form $\mathrm{y}=a+b \mathrm{x}+c \mathrm{x}^{2}$, were $\mathrm{x}$ represents days in the feedlot.

SAMM- South African Mutton Merino.

Quadratic regressions were also fitted to describe the changes in feed intake with time spent in the feedlot for lambs in the various production groups (Table 8). It can be seen that feed intake increased during the trial periods for all of the production groups, as indicated by the positive values of the $b$ parameters.

Table 8 Parameter means ( \pm S.E.) and $R^{2}$ coefficients of determination for the quadratic regressions to describe the change in feed intake for lambs from the Merino, SAMM 2007, SAMM 2008 and Dorper production groups

\begin{tabular}{lcccc}
\hline Production group & $a$ & $b$ & $c$ & $\mathrm{R}^{2}$ \\
\hline Merino & $1.099 \pm 0.06$ & $0.015 \pm 0.00$ & $-0.0001 \pm 0.00$ & 0.98 \\
SAMM 2007 & $1.117 \pm 0.24$ & $0.021 \pm 0.01$ & $-0.0001 \pm 0.00$ & 0.86 \\
SAMM 2008 & $1.106 \pm 0.13$ & $0.016 \pm 0.00$ & $-0.0001 \pm 0.00$ & 0.98 \\
Dorper & $0.644 \pm 0.12$ & $0.038 \pm 0.00$ & $-0.0002 \pm 0.00$ & 0.99 \\
\hline
\end{tabular}

Quadratic equation of the form $\mathrm{y}=a+b \mathrm{x}+c \mathrm{x}^{2}$, were $\mathrm{x}$ represents days in the feedlot.

SAMM- South African Mutton Merino.

\section{Discussion}

A decrease in ADG was seen in Merino lambs during the experimental period. The Merino is a wool sheep and will not grow as efficiently under feedlot conditions as the SAMM or Dorper lambs. The initial high $A D G$ seen in the group slaughtered after 21 days may be as a result of compensatory growth exhibited by 
the lambs on receiving the concentrate diet (Sainz et al., 1995). The dressing percentages of the Merino lambs were also low compared with those of the other production groups. The average dressing percentage of Merino lambs was found to be $43.9 \%$, Snyman \& Herselman (2005) reported dressing percentages of $44.8 \%$ and $44.5 \%$ for grazing Merino lambs, while Van de Vyver et al. (2013) found dressing percentages that varied between $42.0 \%$ and $47.0 \%$. This signifies that the Merino is not such an efficient meat producing breed under feedlot conditions as the SAMM or Dorper.

The SAMM 2008 group had an ADG of $0.350 \mathrm{~kg} / \mathrm{lamb} / \mathrm{day}$ and the 2007 group $0.291 \mathrm{~kg} / \mathrm{lamb} /$ day . Sheridan et al. (2003) found similar daily gains for SAMM on a high energy diet after 28 and 56 days ( 0.330 $\mathrm{kg} / \mathrm{lamb} /$ day and $0.281 \mathrm{~kg} / \mathrm{lamb} /$ day, respectively). The findings of Price et al. (2009) resembled these findings, namely $0.298-0.340 \mathrm{~kg} / \mathrm{day}$, while Brand et al. (2001) found lower daily gains of $0.229-0.267$ $\mathrm{kg} /$ day. The difference in ADG between the two SAMM production years may be because of the difference in average age at weaning. The SAMM 2007 lambs had an average weaning age of $122.3 \pm 0.65$ days and weighed on average $35.5 \pm 0.46 \mathrm{~kg}$, whereas the SAMM 2008 lambs had an average weaning age of 141.0 \pm 0.85 days and weighed $30.0 \pm 0.43 \mathrm{~kg}$. Therefore, the SAMM 2008 production group had spent a longer period on grazing pasture before being weaned and placed in the feedlot than the 2007 production group. This may have had a positive effect on the development of their gastrointestinal tract, as they had a superior ADG on entering into the feedlot. Priolo et al. (2002) also found that lambs that were reared on grass or had grazed for longer had a higher dry matter intake, and therefore a more developed digestive tract. The initial high ADG could also be ascribed to compensatory growth by the 2008 group. The intake of higher quality feed, increased feed intake, lower maintenance requirements (because of restricted movement) and more efficient use of available nutrients, are all factors that can be associated with compensatory growth (Atti \& Ben Salem, 2008), leading to higher growth rates early in the feeding period.

The Dorper breed is an early maturing breed, known for its outstanding growth potential under both extensive and intensive feeding regimes (Schoeman, 2000). On average, the Dorper lambs grew at a rate of $0.274 \mathrm{~kg} /$ day, which is higher than the rate of $0.220-0.230 \mathrm{~kg} /$ day found by Fourie et al. (2009). Dorper lambs tend to put on more localized fat at an earlier age than later maturing breeds, which can be seen as a disadvantage that is amplified by intensive feeding regimes (Claasen, 2008), thus producing fatter carcasses, which are less desirable. These fatter carcasses result in the higher dressing percentages seen in Dorper lambs of $45.5 \%$ and $46.8 \%$ reported by Snyman \& Herselman (2005). Therefore, Dorper lambs are slaughtered at lower live to avoid carcasses being classified as over-fat (Cloete, 2000).

Feed intake was found to increase with age for all the production groups, with quadratic functions fitted to describe the changes with days in the feedlot. A quadratic regression, however, cannot be extrapolated to describe the trends of feed intake outside these feeding periods, as feed intake is expected to increase as the animal grows, and then levels off as the animal nears mature body weight. In contrast, a quadratic function returns to its original starting value, which is not the case with the trend in feed intake, as an animal does not consume less feed as it grows in size. However, the application of quadratic equations to describe the changes in feed intake for these production groups exhibit high $\mathrm{R}^{2}$ values, indicating that most of the variation is accounted for by the models, and so fits the data well. The average feed intake over the slaughter groups for the Merino lambs was found to be $1.557 \mathrm{~kg} / \mathrm{lamb} /$ day, while feed intake for the other breeds was found to be higher than $1.800 \mathrm{~kg} / \mathrm{lamb} / \mathrm{day}$. Van de Vyver et al. (2013), reported dry matter intakes ranging from 0.91 to $1.57 \mathrm{~kg} /$ day for Merino lambs with varying levels of maize silage being included in the diets. Brand et al. (2001) reported feed intakes varying between 1.193 and $1.304 \mathrm{~kg} /$ day, while Price et al. (2009) found that the feed intake of SAMM lambs varied between 1.379 and $1.559 \mathrm{~kg} / \mathrm{day}$. Sheridan et al. (2003) found that the feed intake of SAMM lambs fed feedlot diets varied between 1.746 and $1.893 \mathrm{~kg} / \mathrm{day}$. The level of feed intake depends on the chemical composition and physical form of the diet, and the size of the animal (Lu \& Potchoiba, 1990). These factors influence the amount of feed a lamb can consume, with greater quantities being converted into increased growth.

The SAMM 2007 lambs achieved a high initial FCR of $10.3 \mathrm{~kg}$ feed $/ \mathrm{kg}$ weight gain. This can be attributed to complications from adapting to the finisher diet supplied during the trial. As the rumen environment has evolved to ferment roughage-based diets, it must be adapted gradually to concentrate diets to prevent the occurrence of metabolic diseases because of the build-up of lactic acid in the rumen (Brown et al., 2006). The FCR for the Dorper lambs remained relatively constant throughout the production period, while the Merino and SAMM 2008 lambs attained lower FCRs than the other groups. Even though the SAMM 2008 and Merino groups presented the lowest FCRs, the FCR for these two groups tended to increase during the feeding period. This can be seen with the increase in the level of feed intake (Table 8), with a decrease in growth rate exhibited by these production groups (Table 7). The result is an increase in FCR, making feeding less efficient in these periods. Sheridan et al. (2003) found that SAMM lambs achieved an FCR of 5.56 after 28 days under feedlot conditions, which is similar to that achieved by the SAMM 2008 and Merino lambs. Brand et al. (2001), reported an FCR for SAMM lambs ranging from 4.8 to 5.9, while Price 
et al. (2009) found lower FCRs of 4.51-4.74. It is possible that the Dorper lambs were already depositing fat rather than muscle and it is known that the FCR of animals increase (become less efficient) as the growth rate of the early maturing breed decreases (Mahgoub et al., 2000), as it nears its mature bodyweight (Lawrie, 1998), although the growth rate of the Dorper lambs in this instance still tended to increase with the number of days in feed. Dorper lambs displayed a relatively high average FCR ( $7.5 \mathrm{~kg}$ feed/ $\mathrm{kg}$ weight gain). This may be because Dorper lambs deposit fat at a younger age, and the breed has been developed for arid extensive regions (Cloete et al., 2000), and may not be well adapted to consuming a high-grain low-fibre diet. The Merino showed a favourable average FCR, but the FCR increased with time in the feedlot, which shows that it is not as efficient as a meat-producing breed under feedlot conditions.

According to the South African carcass classification scheme (National Department of Agriculture, 1990), carcasses from lambs with fewer than two permanent incisors with a lean to medium degree of fatness are considered to have the greatest economic value. A measure of the degree of carcass fatness is taken to be the subcutaneous fat depth on the longissimus lumborum muscle. A lean to moderately fat carcass is described as having subcutaneous fat depth ranging between $1 \mathrm{~mm}$ to $7 \mathrm{~mm}$ (National Department of Agriculture, 1990). From these trials it can be seen that Merino lambs could be finished for up to 98 days (weighing less than $51.2 \mathrm{~kg}$ ) before being classed as too fat. SAMM 2007 lambs could finished for up to 84 days before achieving a subcutaneous fat depth greater than $7 \mathrm{~mm}$. However, the SAMM 2008 lambs had a higher fat depth at 84 days compared with the 2007 lambs $(9.3 \mathrm{~mm}$ versus $7.5 \mathrm{~mm})$. This could be expected because the SAMM 2008 lambs were weaned at an older age than the SAMM 2007 lambs, although after a feeding period of 84 days the slaughter weight of lambs from both years was about $59 \mathrm{~kg}$. Dorper lamb carcasses exceeded the moderately fat class limit after 63 days in feed $(10.9 \mathrm{~mm})$, which is considered over-fat. This confirms the statement by Cloete et al. (2000) that Dorper lambs should be slaughtered at lower live weights, possibly closer to $43.3 \mathrm{~kg}$ (42 days) rather than $51.3 \mathrm{~kg}$ (63 days) to avoid carcasses being classed as over-fat, which would result in them having lower market value.

\section{Conclusion}

From this study, it can be seen that Merino lambs entering the feedlot at an age of 109 days achieved superior ADG and FCR after 21 days in the feedlot. To obtain heavier carcasses, Merino lambs may be finished for up to 98 days in the feedlot, weighing about $51 \mathrm{~kg}$, to obtain an ideal lamb carcass. However, the FCR of merino lambs increases after 63 days, making production less efficient. It is recommended that SAMM lambs should be marketed for slaughter after 63 days in the feedlot (ca $52 \mathrm{~kg}$ ) to achieve the required carcass classification, and still show favourable production characteristics. On the other hand, Dorper lambs should probably be marketed soon after 42 days in the feedlot, or at a market weight of about $43 \mathrm{~kg}$, so that the carcasses are not classified as over-fat. These findings serve as a guide to feedlot lamb production and should be considered with current market prices to make an informed decision on the optimal production period.

\section{Acknowledgements}

The authors certify that they have no affiliations with or involvement in any organization or entity with financial or non-financial interest in the subject matter or materials discussed in this manuscript. The authors thank the Technology and Human Resources for Industry Programme (THRIP) for their financial support. The authors also thank Vredendal and Malmesbury abattoirs and Roelcor for their cooperation, and the technical personnel at Elsenburg experimental farm for their assistance.

\section{Authors' Contributions}

Conception and design: TSB; data collection and analysis: EJvdW; drafting of paper: DAvdM; critical revision and final approval of version to be published: LCH.

\section{Conflict of Interest Declaration}

The authors certify that they have no affiliations with any organisation or entity with any financial or non-financial interest in the subject matter or materials discussed in this manuscript.

\section{References}

Aberle, E.D., Forrest, J.C., Gerrard, D.E. \& Mills, E.W. 2001. Principles of Meat Science. Kendall, 4th edn, Hunt , Dubuque, lowa.

Atti, N. \& Ben Salem, H. 2008. Compensatory growth and carcass composition of Barbarine lambs receiving different levels of feeding with partial replacement of the concentrate with feed blocks. Anim. Feed Sci. Tech. 147: 265277.

Brand, T.S., Van der Merwe, G. D., \& Young, D. 2001. Full-fat canola as protein source in diets for finishing lambs. Small Rumin Res. 41: 235-238. 
Brown, M., Ponce, C. \& Pulikanti, R. 2006. Adaptation of beef cattle to high-concentrate diets: Performance and ruminal metabolism. J. Anim. Sci. 84: 25-33.

Claasen, B. 2008. The effect of agricultural production system on the meat quality of Dorper lambs. MSc (Agric) thesis, University of Stellenbosch, South Africa.

Cloete, J.J.E., Hoffman, L.C., \& Cloete, S.W.P. 2008. Carcass characteristics and meat quality of progeny of five merino dam lines, crossed with Dormer and Suffolk sires. S. Afr. J. Anim. Sci. 38(4): 355-366.

Cloete, J.J.E., Hoffman, L.C., Cloete, S.W.P. \& Fourie, J.E. 2004. A comparison between the body composition, carcass characteristics and retail cuts of South African Mutton Merino and Dormer sheep. S. Afr. J. Anim. Sci. 34: 44-51.

Cloete, S.W.P., Snyman, M., \& Herselman, M. 2000. Productive performance of Dorper sheep. Small Rumin Res. 36: 119-135.

Emmans, G.C. 1989. Chapter 8 the growth of turkeys. In C. Nixey \& T.C Grey. Recent advances in turkey science (Poultry Science Symposium number 21). y, Butterworth \& Heinemann.

Fourie, P., Vos, P., \& Abiola, S. 2009. The influence of supplementary light on Dorper lambs fed intensively. S. Afr. J Anim. Sci. 39: 211-214

Gilmour, A.R., Luff, A.F., Fogarty, N.M. \& Banks, R. 1994. Genetic parameters for ultrasonic fat depth and eye muscle measurements in live Poll Dorset sheep. Aust. J. Agr. Res. 45: 1281-1291.

Lawrie, R.A. 1998. Lawrie's meat science, 6th edn. Woodhead Publishing limited. Cambridge, England.

Lu, C.D., \& Potchoiba M.J. 1990. Feed intake and weight gain of growing goats fed diets of various energy and protein levels. J. Anim. Sci. 68: 1751-1759.

Mahgoub, O., Lu, C., \& Early, R. 2000. Effects of dietary energy density on feed intake, body weight gain and carcass chemical composition of omani growing lambs. Small Rumin Res. 37: 35-42.

National Department of Agriculture, 1990. Agricultural Product Standards Act, 1990 Regulations regarding the classification and marketing of meat. ACT No. 119 of 1990: 9-14.

Neser, F.W.C., Erasmus, G.J. \& Van Wyk, J.B. 2000. Genetic studies on the South African Mutton Merino: Growth traits. S. Afr. J. Anim. Sci. 30: 172-177.

Notter, D.R., Kelly, R.F. \& McClaugherty, F.S. 1991. Effects of ewe breed and management system on efficiency of lamb production: II. Lamb growth, survival and carcass characteristics. J. Anim. Sci. 69: 22-33.

Olivier, J.J. 1999. The South African Merino performance testing scheme. Proceedings of the Association for the Advancement of Animal Breeding and Genetics, 119.

Owens, F.N., Dubeski, P. \& Hanson, C.F. 1993. Factors that alter the growth and development of ruminants. J. Anim. Sci. 71: 3138-3150.

Price, M.M., Einkamerer, O.B., De Witt, F.H., Greyling, J.P.C. \& Fair, M.D. 2009. The effect of dietary ionophores on feedlot performance of lambs. S. Afr. J. Anim. Sci. 39: 141-144

Priolo, A., Micol, D., Agabriel, J., Prache, S. \& Dransfield, E. 2002. Effect of grass or concentrate feeding systems on lamb carcass and meat quality. Meat Sci. 62: 179-185.

Sainz, R., De la Torre, F., \& Oltjen, J. 1995. Compensatory growth and carcass quality in growth-restricted and refed beef steers. J. Anim. Sci. 73: 2971-2971.

Sanchez, A. \& Alfonso, M. 1998. Small ruminant production systems and factors affecting lamb meat quality. Meat Sci. 49: 29-64.

Schoeman, S.J. 2000. A comparative assessment of Dorper sheep in different production environments and systems. Small Rumin Res. 36: 137-146.

Sheridan, R., Ferreira, A.V. \& Hoffman, L.C. 2003. Production efficiency of South African Mutton Merino lambs and Boer goat kids receiving either a low or a high energy feedlot diet. Small Rumin Res. 50: 75-82.

Snyman, M., \& Herselman, M. 2005. Comparison of productive and reproductive efficiency of Afrino, Dorper and Merino sheep in the False Upper Karoo. S. Afr. J. Anim. Sci. 35(2): 98-108.

Van de Vyver, W., Beukes, J., \& Meeske, R. 2013. Maize silage as a finisher feed for merino lambs. S. Afr. J. Anim. Sci. 43: $116-120$. 